\title{
Suicide and the Media: From Werther to Papageno Effects - A Selective Literature Review
}

\author{
By Thomas Niederkrotenthaler and Benedikt Till
}

\begin{abstract}
Et betydelig antall studier har vist at sensasjonspregete skildringer av selvmord i media kan utløse imitasjonsselvmord; dette er ofte omtalt som «Werther-effekten». For å forhindre skadelige medieeffekter, har nasjonale og internasjonale organisasjoner utviklet anbefalinger for omtale av selvmord i mediene for å endre praksis i hvordan selvmord beskrives og for å styrke fokuset på selvmordsforebyggende aspekter. I løpet av det siste tiåret har man fått mer kunnskaper som viser at visse typer medieomtale av selvmord kan ha forebyggende effekt. Særlig mediesaker som beskriver personlige erfaringer med selvmordstanker og hvordan man kan overvinne og takle vanskelige livssituasjoner, har vist seg å redusere suicidalitet $\mathrm{i}$ enkelte grupper. Denne beskyttende effekten har blitt kalt Papageno-effekten. I denne artikkelen gir vi en selektiv oversikt over aktuell litteratur om Werther- og Papagenoeffektene for forskjellige typer medier, og legger særlig vekt på nye kunnskaper om Papageno-effekten generert fra randomisert kontrollerte studier. Vi viser hvordan disse effektene kan utnyttes i selvmordsforebyggende arbeid ved samarbeid med media, og peker på fortsatte mangler i kunnskapene som må fokuseres i fremtidig forskning.
\end{abstract}

A considerable number of studies have shown that sensationalist protrayals of suicide in the media trigger imitational suicides, often referred to as Werther effect. In order to prevent harmful media effects, media recommendations for suicide reporting have been developed and implemented by national and international organizations in order to change the conversation on suicide and include and emphasize suicide-preventive aspects. In the last decade, additional evidence is emerging that some media portrayals of suicidality might help prevent suicide. Specifically, media potrayals featuring stories of personal experience of suicidal ideation and how to overvcome and cope with adverse circumstances have been shown to decrease suicidality in some audiences. This protective effect has been labeled Papageno effect. In this paper, we provide a selective review of current literature on the Werther and Papageno effects for different types of media and put a particular emphasis on new evidence on the Papageno effect from randomized controlled trials. We highlight how the combined evidence of media effects on suicide and/or suicidal ideation can help suicide prevention by collaboration with the media, and point to specific gaps in knowledge that need to be addressed in future research. 
RESEARCHERS FROM AROUND the world have compiled a large corpus of research about the impact of media on suicidality in the last few decades (Pirkis \& Blood, 2010; WHO, 2017). With the media playing an increasingly important role in suicide prevention, the task to complement research on harmful media effects of suicide portrayals with research on potential benefits of media discourse on suicidality has become a priority in suicide research (Niederkrotenthaler et al., 2014; Niederkrotenthaler \& Stack, 2017). Therefore, the aim of this selective literature review is to provide an overview on current scientific evidence on how suicide portrayals in the media can negatively and positively impact audiences and discuss recent key findings on this topic.

\section{Harmful media portrayals: The Werther effect}

Based on more than 150 studies in the topic area, there is clear evidence today that sensationalist and repetitive reports on suicides in news media can trigger imitative suicides (Sisask \& Värnik, 2012; WHO, 2017; Niederkrotenthaler \& Stack, 2017). This effect is often referred to as Werther effect based on an alleged 'suicide-epidemic' among young men after the publication of Goethe's novel The sorrows of the young Werther, which concludes with the protagonist's suicide (Phillips, 1974). Since Phillips' (1974) seminal study, the Werther effect has been replicated in numerous studies in different cultural regions, particularly for suicide portrayals in news media (Pirkis \& Blood, 2001a; WHO, 2017). An overview of studies on the Werther effect can be found, among others, in systematic reviews by Pirkis and Blood (2001a; 2001b; 2010), Sisask and Värnik (2012), and Stack (2005), and Niederkrotenthaler et al. (2012). The Werther effect has been considered to be particularly strong for sensationalist reporting on celebrity suicides (Niederkrotenthaler et al., 2012). A recent example is the sensationalist reporting on Robin William's suicide, which was associated with a $10 \%$ increase in suicides (an excess of 1,841 suicides) in the United States from August to December 2014 (Fink et al., 2018).

Although there is less evidence overall for fictional media such as fictional films and television series to trigger suicidal ideation and behavior, mainly due to the smaller number of studies in this area, there are some studies that clearly indicate that fictional portrayals of suicides can also influence real-world suicidal behaviours. A recent meta-analysis suggested that there was no overall evidence to support that fictional media 
might result in imitational suicides (Ferguson, 2019). Considering, however, that the absence of evidence does not equal evidence of absence of an effect (see Alderson, 2004), and in the presence of several studies that have indeed found associations of fictional media content with subsequent increases in suicides, Ferguson's (2019) conclusion appears to be too strong. Schmidtke and Häfner (1988), for example, found an increase in railway suicides among adolescents aged 15-29 in Germany following the broadcast of a television series portraying the railway suicide of a 19-year-old student in Germany. Gould and Shaffer (1986) reported an

\section{While not exhaustive,} these studies clearly suggest that some fictional portrayals do indeed trigger suicidal behavior. increase of suicide in teenagers in New York after the broadcast of fictional films on suicide. Some studies have also used experimental designs to test the effects of fictional

media, using suicidal thoughts as the outcome variable. The results of a laboratory experiment in Austria showed that viewers with comparatively higher vulnerability (i.e., baseline suicidality above the median of the sample) experienced an increase of suicidal ideation after watching a film concluding with the tragic suicide of the protagonist (Till et al., 2015). This effect was particularly strong in study participants who strongly identified with the female protagonist who died by suicide (Till et al., 2015). While not exhaustive, these studies clearly suggest that some fictional portrayals do indeed trigger suicidal behavior, and suggest that both vulnerability and identification with the featured characters might play a role in this. Most recently, further evidence was found for the first season of the Netflix series 13 Reasons Why, which features the female protagonist's explicit and graphic suicide (e.g., Bridge et al., in press; Cooper et al., 2018; Niederkrotenthaler et al., 2019). The release of that series was associated with a $13 \%$ increase in adolescent suicides in the United States in the three months post-release, and the proportional increase was particularly strong among girls (Niederkrotenthaler et al., 2019). Several help organizations had provided resources to help parents, schools, and community leaders discuss the series with adolescents soon after the release of season one (Arendt et al., 2017; see e.g., https://www.13reasonswhytoolkit.org).

So far, the underlying psychological mechanisms of the Werther effect are only partially understood. Based on concepts of suicidal development by Ringel (1976) and Shneidman (1995) it is commonly assumed that suicidal individuals typically oscillate between life sustaining and death-focused impulses. In this state of ambivalence toward life and death, media messages on suicide may influence the outcome of this inner conflict (Ringel, 1976; Shneidman, 1995). Other authors have explained the Werther effect by referring to Bandura's (1977) social learning theory, which suggests that portrayals of behavior enhance learning processes and may thereby promote and stimulate suicidal behaviors (Blood \& Pirkis, 2001), or by social identification processes (Arendt et al., 2016; Fu \& Yip, 2009; Stack, 1992). In accordance with these assumptions, studies have found that the risk for additional suicides after sensationalist suicide portrayals in newspapers was greater when social similarity between model and recipients was high (Niederkrotenthaler et al., 2009), and identification mediated the increase in suicidal ideation among viewers with comparatively higher baseline suicidality when watching a film concluding with the protagonist's suicide (Till et al., 2015). These findings suggest that both, vulnerability to suicide as described by authors such as Ringel (1976) and Shneidman (1995) in their concept of suicidal constriction, but also social identification might play a role in increases in suicide risk and potentially imitative behaviours. Clearly, further research is necessary to further investigate these hypotheses.

\section{Prevention of imitational suicides}

In order to prevent imitational suicides after media portrayals of suicides, international organizations and national stakeholders in many countries have developed and implemented media recommendations for suicide reporting (Etzersdorfer \& Sonneck, 1998; Pirkis et al., 2006; WHO, 2017). In Austria, for example, media recommendations were already implemented in 1987 , in response to a sharp increase in suicides and suicide attempts in the Vienna subway. These suicides were of exceptional interest to the mass media and each case appeared to boost reporting on these suicides in the local media (Etzersdorfer \& Sonneck, 1998; Etzersdorfer et al., 1992; Niederkrotenthaler \& Sonneck, 2007). The adoption of these recommendations resulted in a more careful and less sensationalist reporting of suicide, and there was an immediate decrease in suicides and suicide attempts in the Viennese subway by more than 70 \% (Etzersdorfer \& Sonneck, 1998; Etzersdorfer et al., 1992; Niederkrotenthaler \& Sonneck, 2007). In the last two decades, some evidence has been accumulated from several countries regarding positive effects of the implementation of media guidelines, particularly on the quality of suicide reporting (Michel et al., 2000; Pirkis et al., 2009; Sisask \& Värnik, 2012). More research, however, on the effectiveness of media guidelines for suicide reporting and implementation strategies is needed, and it remains unclear which implementation strategy works best in various settings, including both online and traditional media settings (Niederkrotenthaler \& Stack, 2017). Furthermore, most of the available ressources target news media rather than fictional 


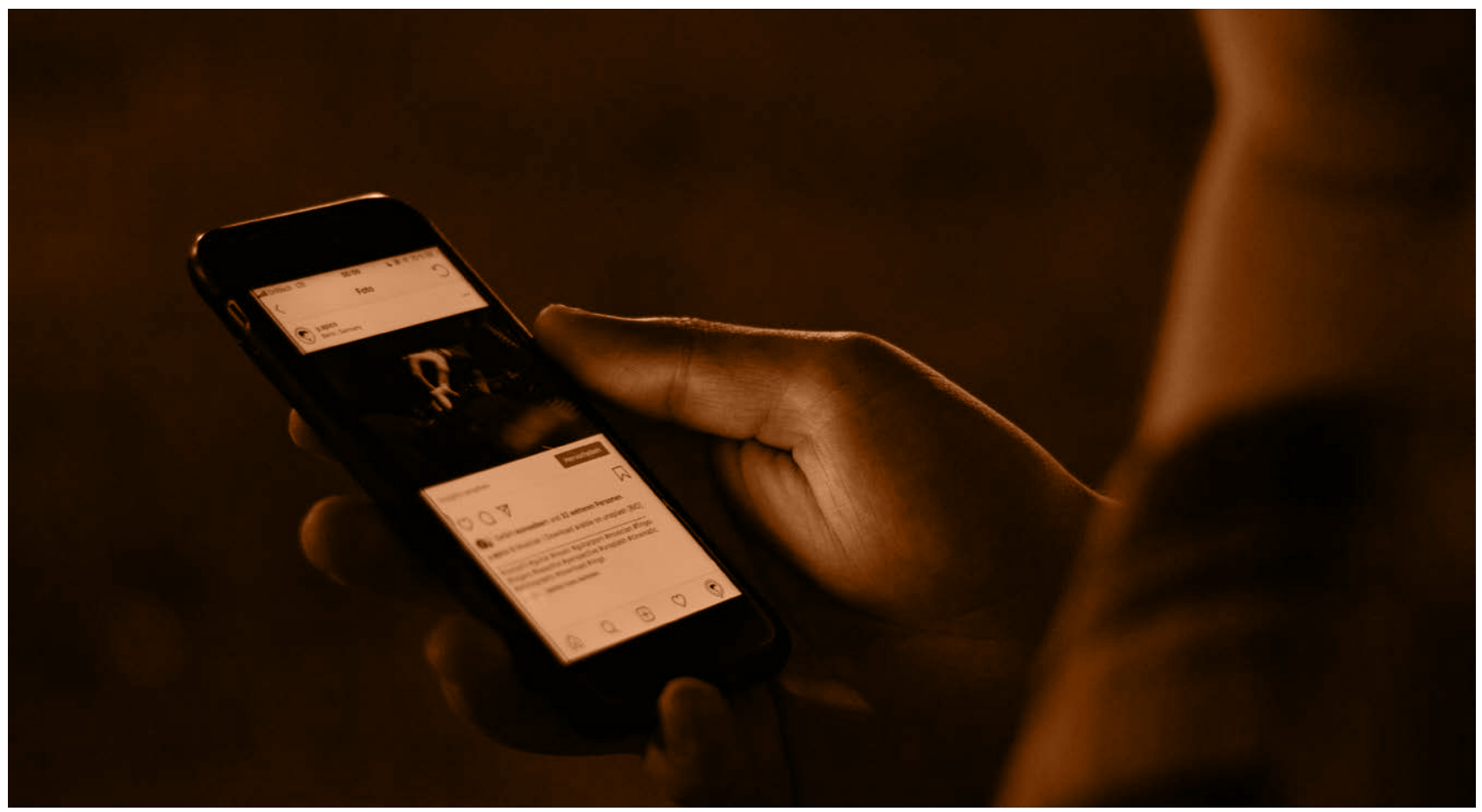

media. This is in spite of public health agencies as well as interested filmmakers and producers in the film industry who have requested recommendations for suicide portrayals in fictional films and TV series. Beside the respective ressources from organizations such as Mindframe in Australia and the Samaritans in the United Kingdom (Mindframe, 2007; Samaritans, 2017), the US National Action Alliance for Suicide Prevention (2019) has specifically developed recommendations for the portrayal of suicide in collaboration with the entertainment industry. These recommendations, however, have not been subject to any evaluation work so far.

Beside their primary aim of reducing imitative suicides, media recommendations for suicide reporting also emphasize the necessity to reduce stigmatization of suicidal ideation and suicidal individuals as well as organizations dedicated to assisting individuals with suicidal thoughts. Therefore, the recommendation typically also includes recommendations to use neutral language for suicide and refrain from stigmatizing or misleading wording such as reflected in phrases like "successful suicide" or "commit" suicide (e.g., WHO, 2017). A recent experiment explicitly investigated the possible effect of one specific language recommendation in German-language media recommendations. In German, there are three different words for suicide: Suizid ("suicide"), Selbstmord ("self-murder"), and Freitod ("free death"). The neutral term Suizid is recommended by suicide prevention experts, because it does neither condemn nor euphemize suicide, whereas the other two phrases convey associative meanings related to con- cepts such as free will (Freitod) as well as crime and murder (Selbstmord) (Arendt, 2018; Arendt, Scherr, Niederkrotenthaler, \& Till, 2018). In a web-based randomized controlled trial testing the effects of newspaper articles that differed only with regard to the use of the specific word for "suicide", it was shown that participants reading the articles with the referent Freitod showed greater attitudinal support for suicide among individuals suffering from incurable diseases (Arendt, Scherr, Niederkrotenthaler, \& Till, 2018). The findings of this study show that a single word in suicide news reporting can make a difference when it comes to public attitudes and perceptions on suicide. Based on the ubiquitous presence of such connotations in the media and elsewhere, we can only assume that these findings only capture the tip of an iceberg when it comes to how language influences public perceptions of suicide.

\section{Protective media portrayals: The Papageno effect}

Although sensationalist media reports can trigger imitational suicides, by far not all portrayals of suicide in the media trigger imitational suicides (Stack, 2005; Niederkrotenthaler \& Stack, 2017). Suicide reports without sensationalist characteristics are typically not associated with suicide rates (Niederkrotenthaler, 2010a), and it is widely assumed that suicide can be reported without increasing suicide rates if they are consistent with media recommendations, and do not flood the public with unnecessarily repetitive reporting of the same suicide case (WHO, 2017). However, for a long time, researchers only focused on the identification 
of harmful media portrayals, in spite of the possibility that some media reports might also have protective potentials. In the first study that identified a possible protective effect of media reporting, Niederkrotenthaler et al. (2010a) conducted a content analysis of 490 newspaper articles on suicide that were published in Austria within a 6-month-period. The study found, consistent with a possible Werther effect, an increase of suicides after sensationalist suicide reports. However, the novel finding was that this study also found a decrease of suicides after the publication of a different type of media report, which specifically focused on individuals who successfuly coped with their suicidal crises. Based on the protagonist in Mozart's opera The magic flute, who successfully mastered his suicidal crisis with the help of "the Three Boys", who, in the opera, remind him of his alternatives to suicide, this possible preventive effect was coined 'Papageno effect' (Niederkrotenthaler at al., 2010a; 2010b). A potential explanation for a protective effect of these media reports may derive from the inherent social normative messages delivered in stories of hope and recovery. Different to the detrimental effects seen for sensationalist media reports on suicides, stories of hope of recovery might promote active, constructive coping with personal problems, and help to broaden the perspective in suicidal individuals and emphasize alternative options of dealing with adverse circumstances than suicide (Niederkrotenthaler et al., 2014). To further test the Papageno hypothesis and possible mechanisms, individual-level studies are necessary. Ecological studies such as the study above provide important insights for hypothesis-building, but pre-post designs and aggregate data generally have low specificity because it remains unclear to what extent

Table 1. Overview of Published Randomized Controlled Trials on the Papageno effect.

\begin{tabular}{|c|c|c|c|c|}
\hline Source & Sample & Analyzed Media & Analyzed Outcome-Variables & Protective Effect \\
\hline $\begin{array}{l}\text { Till, Strauss, } \\
\text { Sonneck, \& } \\
\text { Niederkrotenthaler } \\
(2015)\end{array}$ & $\begin{array}{l}95 \\
\text { adults of the } \\
\text { general } \\
\text { population }\end{array}$ & $\begin{array}{l}\text { Hollywood } \\
\text { film }\end{array}$ & $\begin{array}{l}\text { Suicidal ideation, life satisfaction, } \\
\text { depression, mood, self-worth, } \\
\text { assumed benevolence of the world }\end{array}$ & $\begin{array}{l}\text { Increase in life satisfaction and } \\
\text { assumed benevolence of the world }\end{array}$ \\
\hline $\begin{array}{l}\text { Arendt, Till, \& } \\
\text { Niederkrotenthaler } \\
(2016)\end{array}$ & $\begin{array}{l}112 \\
\text { university } \\
\text { students }\end{array}$ & $\begin{array}{l}\text { News } \\
\text { article }\end{array}$ & Suicide cognitions & $\begin{array}{l}\text { Decrease in suicide cognitions } \\
\text { among participants with low } \\
\text { identification with the portrayed } \\
\text { adverse circumstances }\end{array}$ \\
\hline $\begin{array}{l}\text { Till, Tran, } \\
\text { Voracek, \& } \\
\text { Niederkrotenthaler } \\
(2017)\end{array}$ & $\begin{array}{l}161 \\
\text { adults of the } \\
\text { general } \\
\text { population }\end{array}$ & $\begin{array}{l}\text { Educative } \\
\text { website }\end{array}$ & $\begin{array}{l}\text { Primary: Suicidal ideation } \\
\text { Secondary: Mood, suicide- } \\
\text { prevention-related knowledge, } \\
\text { attitudes toward suicide, attitudes } \\
\text { toward seeking professional help }\end{array}$ & $\begin{array}{l}\text { Primary: Decrease in suicidal } \\
\text { ideation among participants with } \\
\text { comparatively higher suicidality } \\
\text { Secondary: Increase in suicide- } \\
\text { prevention-related knowledge }\end{array}$ \\
\hline $\begin{array}{l}\text { Arendt, Scherr, } \\
\text { Niederkrotenthaler, } \\
\text { Krallmann, \& Till } \\
\text { (2018) }\end{array}$ & $\begin{array}{l}273 \\
\text { adults of the } \\
\text { general } \\
\text { population }\end{array}$ & $\begin{array}{l}\text { News } \\
\text { article }\end{array}$ & $\begin{array}{l}\text { Suicide-related knowledge, } \\
\text { intentions to provide adequate help } \\
\text { to suicidal individuals, enjoyment, } \\
\text { preceived knowledge gain }\end{array}$ & $\begin{array}{l}\text { Increase in suicide-related } \\
\text { knowledge and intentions to provide } \\
\text { adequate help to suicidal individuals } \\
\text { after reading an article that focuses } \\
\text { on coping with suicidal crises and } \\
\text { debunking suicide myths }\end{array}$ \\
\hline $\begin{array}{l}\text { King, Schlichthorst, } \\
\text { Spittal, Phelps, \& } \\
\text { Pirkis (2018), King } \\
\text { et al. (2018) }\end{array}$ & $\begin{array}{l}337 \\
\text { adult men of } \\
\text { the general } \\
\text { population }\end{array}$ & $\begin{array}{l}\text { Three-part } \\
\text { documentary }\end{array}$ & $\begin{array}{l}\text { Primary: Intentions to seek help } \\
\text { Secondary: Likelihood of recom- } \\
\text { mending a friend to seek help, } \\
\text { conformity to masculine norms, } \\
\text { experience of masculinity, social } \\
\text { support, psychological distress, } \\
\text { well-being, resilience, suicidality, } \\
\text { feedback on the documentary }\end{array}$ & $\begin{array}{l}\text { Primary: Increase in intentions } \\
\text { to seek help } \\
\text { Secondary: Increase in likelihood } \\
\text { of recommending a friend to seek } \\
\text { help, decrease in conformity to } \\
\text { masculine norms }\end{array}$ \\
\hline $\begin{array}{l}\text { Till, Arendt, } \\
\text { Scherr, \& } \\
\text { Niederkrotenthaler } \\
\text { (2019) }\end{array}$ & $\begin{array}{l}527 \\
\text { adults of the } \\
\text { general } \\
\text { population }\end{array}$ & $\begin{array}{l}\text { News } \\
\text { article }\end{array}$ & $\begin{array}{l}\text { Primary: Suicidal ideation } \\
\text { Secondary: Suicide-prevention- } \\
\text { related knowledge }\end{array}$ & $\begin{array}{l}\text { Primary: Decrease in suicidal } \\
\text { ideation } \\
\text { Secondary: Increase in suicide- } \\
\text { prevention-related knowledge }\end{array}$ \\
\hline
\end{tabular}


people who died or did not die by suicide before and after the media portrayal were actually exposed to the media coverage (Pirkis \& Blood, 2001a). Thus, where possible and ethical, findings from ecological research designs need to be followed by individual-level studies, e.g., randomized controlled trials (Blood \& Pirkis, 2001; Pirkis \& Blood, 2001a; 2001b; Niederkrotenthaler et al., 2014; Pouliot et al., 2011). In contrast to ecological studies, individual-level studies cannot assess suicide as an outcome variable, but it is possible to explore the impact of media exposure on suicide-related measures such as suicidal ideation and other risk factors for suicide (Niederkrotenthaler et al., 2014; Pirkis \& Blood, 2001a, 2001b).

An overview of randomized controlled trials on the Papageno effect is provided in Table 1 . Stories of suicide attempt survivors and individuals with personal experience of suicidal ideation or bereaved by suicide have been at the forefront of the Papageno effect hypothesis (Niederkrotenthaler et al., 2010a), and their preventive potential has also become more and more acknowledged in suicide prevention overall in recent years (National Action Alliance for Suicide Prevention, 2014). However, the effects of acknowledging own personal experiences of suicidal ideation in a media setting has not been investigated in detail. In a recent randomized controlled trial, Till et al. (2019) explored the effects of educative news articles featuring interviews with experts with vs. without disclosure of own personal experience of suicidal ideation. The participants read a news article featuring an interview with a suicide expert who stated that suicidal ideation, different from suicide, was very prevalent, offered advice on how to cope with suicidal thoughts, and explained how families and friends can support individuals in crisis. The articles in the two intervention groups were identical, but in one group, the expert also reported personal experience with own suicidal ideation when asked by the journalist if she had ever experienced a suicidal crisis herself. The expert explained that she once was in a suicidal crisis as a young adult and how she overcame her crisis. The expert in the other intervention group did not disclose any personal experience of suicidal ideation. Participants of the control group read an interview with a medical expert not related to suicide (Till et al., 2019). The results showed that participants experienced a decrease in suicidal ideation and an increase of suicide-prevention-related knowledge in both intervention groups (Till et al., 2019) but not in the control group, replicating previous findings from experimental studies on news articles on the Papageno effect (Arendt et al., 2016; Arendt et al., 2018). Both, experts with and without disclosure of personal experiences of suicidal ideation, appeared similarly effective in reducing suicidal ideation, and their stories also increased suicide-prevention related knowledge in the study participants (Till et al., 2019).
One of the major gaps in the literature currently is that no studies are available for media impacts of Papageno-style media portrayals on vulnerable individuals, e.g. individuals with recent or current suicidal ideation, or with a recent suicide attempt, who are a core target group in many media interventions. This dilemma, which applies to suicide research in general (i.e. suicidality is often an exclusion criterion e.g. in pharmaceutical research), means that potentially wrong generalizations about media effects are consistently made based on studies that excluded suicidal individuals. Based on the encouraging results from non-suicidal study participants, currently several randomized controlled trials are underway to test media effects of stories of hope and recovery on individuals with some degree of vulnerability. Specific media contents,

\section{This dilemma, which applies to suicide research in general ..., means that poten- tially wrong generalizations about media effects are consistently made based on studies that excluded suicidal individuals.}

particularly also disclosures of personal experiences with suicidality by the featured protagonist, might have a different effect in vulnerable individuals as compared to general population settings. In a recently completed randomized controlled trial, we found accordingly that there was a beneficial effect on suicide risk in participants who read a news article featuring a story on coping with suicidal crises delivered by an individual with personal experience of suicidal ideation as compared to the control group. The effect was particularly pronounced for individuals with recent suicide attempt, but was not found when a similar story was delivered by a mental health expert (Niederkrotenthaler \& Till, under review). This finding suggests that some vulnerable individuals benefit from stories of personal experience of suicidal ideation that are delivered by individuals who experienced suicidality in the past and managed to cope with it.

All of the outlined findings on the Papageno effect stem from traditional media types, but many resources on suicide prevention are now developed for online media, making them a priority for suicide research. In a recent randomized controlled trial, the effects of three different educative suicide prevention websites that are freely available on the Internet and target adolescents and young adults were investigated. Like many educative websites on suicide, these websites featured professional resources along with stories of personal experience of suicidality, including stories of suicide or suicidal ideation among family and friends. Suicidal 
ideation and suicide-prevention-related knowledge were assessed before and immediately after website exposure as well as one week later. The results suggested a medium-sized reduction of suicidal ideation among users with comparatively higher vulnerability and a large increase in suicide-prevention-related knowledge in all users of suicide prevention websites compared to the control group (Till et al., 2017). Both effects were also sustained one week later, suggesting that these websites are effective in yielding a protective impact that persists beyond immediate exposure (Till et al, 2017).

Besides their impact on suicidal ideation, other outcome variables such as intentions to seek help and actual help-seeking are also relevant to determine the overall suitability of suicide prevention materials in the media. A recent project in Australia called Man Up developed a documentary examining how society shaped the way men and boys saw themselves and their behavior and the way in which this might affect their mental health. Several studies investigated the impact of the show and demonstrated an increase in their primary outcome variables, i.e. intentions to seek help and improved attitudes towards professional help, although no effects were found in secondary outcomes such as suicidal ideation (King, Schlichthorst Reifels et al., 2018; King, Schlichthorst, Spittal et al., 2018; Schlichthorst et al., 2018). Different media inputs might have an effect on different outcomes that are relevant to suicide prevention, and more research is needed to disentangle which media contents work best in which audiences, and for which outcome measures. Accordingly, randomized controlled trials are currently under way to test media portrayals targeting high-school students and lesbian, gay and bisexual persons in their coming-out, respectively (Braun et al., 2019; Kirchner et al., 2019), and much more research is needed to investigate various media contents in diverse audiences and settings.

The Papageno effect might also occur in settings that are often neglected in suicide research and prevention, including non-professional suicide message boards. These boards are typically set up by lay individuals and do not consistently collaborate with mental health professionals. Some support for a possible Papageno effect in these settings comes from a content analysis of postings in German-language message boards, which included both so-called against-suicide boards (which typically collaborate with professional help services and encourage help-seeking), and pro-suicide boards, which typically encourage the discussion of suicide methods and do not collaborate with professionals (Niederkrotenthaler et al., 2016). Not surprisingly, the study found that indicators of possible psychological improvements by the end of a specific thread (e.g., a poster saying "I feel less suicidal now") was more frequent in "against-suicide message boards", where $44 \%$ of posters indicated some improvement, as compared to only $9 \%$ of posters in "pro-suicide" boards. However,

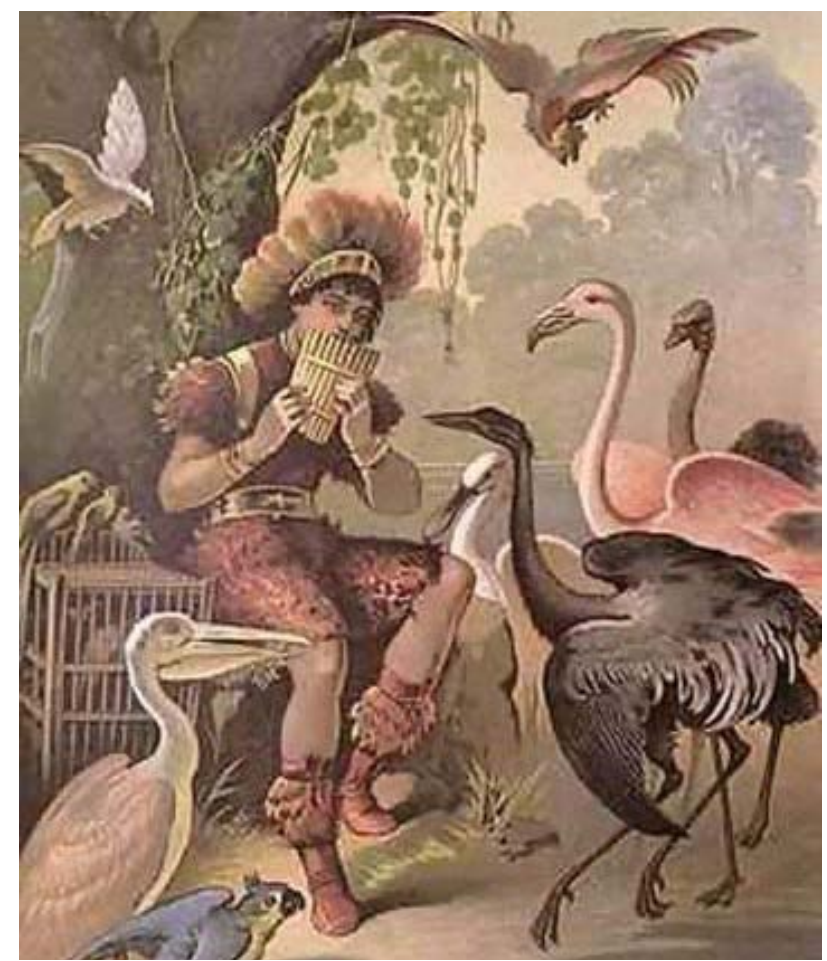

Illustration of Papageno calling the birds of the forest with his magic flute by Carl Offterdinger. Photo by Stefano Bianchetti/Corbis via Getty Images.

several elements and patterns in communication were associated with verbal expressions of psychological improvement independent of board type. If posters who responded in a thread applied active listening, mentioned own stories of personal experiences with suicidal ideation and how to cope, and if they provided constructive advice, these communication patterns were associated with verbal expressions of psychological improvement in those who were targeted by these responses (Niederkrotenthaler et al., 2016). In other words, posters in non-professional suicide message boards showed self-reported signs of reduced suicide risk, if other users provided stories on how they coped with adverse circumstances and overcame their suicidal crises (a classic lay communications strategy) or used strategies known to be effective also in professional settings, e.g. active listening. These findings suggest that a setting-specific communication approach might help improve communications in non-professional settings relevant to suicide prevention. Because of the considerable risks involved particularly with pro-suicide message boards, more emphasis needs to be put on pro-suicide settings in future research and prevention initiatives.

\section{Conclusions}

Recent findings on media effects indicate that suicide portrayals across various media types, including print media, fictional films and television series, as well as 
online media, can have both harmful and protective effects, depending on the story focus and who the audience is. Sensationalist repetitive portrayals of suicide that focus on suicide methods and suicidal acts are likely to trigger imitational suicides (Werther effect), while stories that hightlight how to cope with adverse circumstances and master suicidal crises are likely to reduce suicidal ideation in some audiences (Papageno effect). Harmful effects can be prevented by portraying suicide consistent with media recommendations (e.g., WHO, 2017). Providing accurate information about where to seek help, featuring stories of hope and recovery, not describing details of suicide methods, and refraining from sensationalizing or normalizing suicide are, amongst others, important elements in suicide reporting to prevent imitational suicides (WHO, 2017).

Furthermore, evidence on the Papageno effect might inform both, suicide-related reporting and suicide awareness campaigns. Stories of personal experience of suicidal ideation focusing specifically on how to overcome a suicidal crisis may be particularly useful for preventive efforts in these areas. Reporting practices highlighting treatment options and stories of treatment success in addition to mortality rates have been used for many years in other public health areas such as the prevention of cancer and cardiovascular diseases (Till \& Niederkrotenthaler, 2014). Highlighting possibilities of coping with suicidal ideation and managing ones lives might help to reduce the stigma of suicidality without running the risk of causing harm among vulnerable individuals.

\section{Acknowledgements}

Research on effects of suicide prevention websites (P-23659-B11), suicide prevention public service announcements targeting adolescents (KLI627-B3O), and effects of It Gets Better suicide prevention videos targeting lesbian, gay, bisexual and questioning adolescents (P30918-B27) have been funded by the Austrian Science Fund (FWF).

Parts of this article were published in modified form in De Leo \& Postuvan (Eds.) (2019), Reducing the Toll of Suicide: Resources for Communities, Groups, and Individuals. Hogrefe Publishing. www.hogrefe.com and in Niederkrotenthaler \& Stack (Eds.) (2017), Media \& suicide: International perspectives on research, theory, \& policy. Transaction Books.

\section{REFERENCES}

Alderson, P. (2004). Absence of evidence is not evidence of absence: We need to report uncertain results and do it clearly. BMI, 328, 476-477.

Arendt, F. (2018). Framing suicide - investigating the news media and public's use of the problematic suicide referents Freitod and Selbstmord in German-speaking countries. Crisis, 39, 70-73.

Arendt, F., Scherr, S., Niederkrotenthaler, T., Krallmann, S., \& Till, B. (2018). Effects of awareness material on suicide-related knowledge and the intention to provide adequate help to suicidal individuals. Crisis, 39, 47-54.
Arendt, F., Scherr, S., Niederkrotenthaler, T., \& Till, B. (2018). The role of language in suicide reporting: Investigating the influence of problematic suicide referents. Soc Sci Med, 208, 165-171.

Arendt, F., Scherr, S., Till, B., Prinzellner, Y., Hines, K., \& Niederkrotenthaler, T. (2017). Suicide on TV: minimising the risk to vulnerable viewers. BMI, 358, i3 876 .

Arendt, F., Till, B., \& Niederkrotenthaler, T. (2016). Effects of suicide awareness material on implicit suicide cognition: A laboratory experiment. Health Commun, 31, 718-726.

Bandura, A. (1977). Social learning theory. Englewood Cliffs, NI: PrenticeHall.

Blood, R. W., \& Pirkis, I. (2001). Suicide and the media. Part III: Theoretical issues. Crisis, 22, 163-169.

Braun, M., Till, B., Pirkis, I., \& Niederkrotenthaler, T. (2019, September). Suicide Prevention Spots Targeting Adolescents: A Qualitative Study about the Production Process and the Participant's Experiences. Paper presented at the zoth World Congress of the International Association for Suicide Prevention "Breaking Down Walls \& Building Bridges", Derry-Londonderry, United Kingdom.

Bridge, I. A., Greenhouse, I. B., Ruch, D., Stevens, I., Ackerman, I., Sheftall, A. H.,...Campo IV. (in press). Association between the release of Netflix's 13 Reasons Why and suicide rates in the United States: An interrupted times series analysis. I Am Acad Child Adolesc Psychiatry. Available at: https:// www.jaacap.org/article/So89o-8567(19)30288-6/pdf

Cooper, M. T., Bard, D., Wallace, R., Gillapsy, S., \& Deleon, S. (2018). Suicide attempt admissions from a single children's hospital before and after the introduction of Netflix series 13 Reasons Why. I Adolesc Health, 63, 688-693.

De Leo, D., \& Postuvan, V. (Eds.) (2019). Reducing the toll of suicide: Resources for communities, groups, and individuals. Boston, MA: Hogrefe.

Etzersdorfer, E., \& Sonneck, G. (1998). Preventing suicide by influencing mass-media reporting. The Viennese experience 1980-1996. Arch Suicide Res, 4, 67-74.

Etzersdorfer E, Sonneck G, Nagel Kuess S. (1992). Newspaper reports and suicide. N Engl I Medicine, 327, 502-503.

Ferguson, CI. (2019). 13 Reasons Why Not: A methodological and meta-ana lytic review of evidence regarding suicide contagion by fictional media. Suicide Life Threat Behav, 49, 1178-1186.

Fink, D. S., Santaella-Tenorio, I., \& Keyes, K. M. (2018). Increase in suicides the months after the death of Robin Williams in the US. PLOS ONE, 13, eo191405.

Fu, K.W., \& Yip, P.S. (2009). Estimating the risk for suicide following the suicide deaths of three Asian entertainment celebrities: a meta-analysis approach. I Clin Psychiatry, 70, 869-878.

Gould, M. S., \& Shaffer, D. (1986). The impact of suicide in television movies: Evidence of imitation. N Engl I Medicine, 315, 690-694.

King, K. E., Schlichthorst, M., Reifels, L., Keogh, L., Spittal, M. I., Phelps, A. \& Pirkis, I. (2018). Impacts of a documentary about masculinity and men's health. A I Mens Health, 12, 1604-1614.

King, K. E., Schlichthorst, M., Spittal, M. I., Phelps, A. \& Pirkis, I. (2018). Can a documentary increase help-seeking intentions in men? A randomised controlled trial. I Epidemiol Community Health, 72, 92-98.

Kirchner, S., Till, B., Plöderl, M. \& Niederkrotenthaler, T. (2019, September) A qualitative content analysis of the Austrian „It Gets Better"-videos for LGBTIQ adolescents. Paper presented at the 3oth World Congress of the International Association for Suicide Prevention "Breaking Down Walls \& Building Bridges", Derry-Londonderry, United Kingdom.

Michel, K., Frey, C., Wyss, K., \& Valach, L. (2000). An exercise in improving suicide reporting in print media. Crisis, 21, 71-79.

Mindframe. (2007). Mental illness and suicide. A Mindframe resource for stage and screen. Canberra, Australia: Commonwealth of Australia. 
National Action Alliance for Suicide Prevention. (2014). The way forward: Pathways to hope, recovery, and wellness with insights from lived experiences. Washington, DC: National Action Alliance for Suicide Prevention.

National Action Alliance for Suicide Prevention. (2019). National recommendations for depicting suicide. Retrieved from https://heactionalliance.org/ messaging/entertainment-messaging/national-recommendations

Niederkrotenthaler, T., Fu, K. W., Yip, P. S., Fong, D. Y., Stack, S., Cheng, Q., \& Pirkis, I. (2012). Changes in suicide rates following media reports on celebrity suicide: a meta-analysis. I Epidemiol Community Health, 66, 1037-1042.

Niederkrotenthaler, T., Gould, M., Sonneck, G., Stack, S., \& Till, B. (2016). Predictors of psychological improvement on non-professional suicide message boards: Content analysis. Psychol Med, 46, 3429-3442.

Niederkrotenthaler, T., Reidenberg, D. I., Till, B., \& Gould, M. (2014). Increasing help-seeking and referrals for individuals at risk for suicide by decreasing stigma: The role of mass media. Am I Prev Med, 47, 235-243.

Niederkrotenthaler, T., \& Sonneck, G. (2007). Assessing the impact of media guidelines for reporting on suicides in Austria: interrupted times series analysis. Aust N Z I Psychiatry, 41, 419-428.

Niederkrotenthaler, T. \& Stack, S. (Eds.) (2017). Media \& suicide: international perspectives on research, theory, \& policy. Piscataway, NI: Transaction Books.

Niederkrotenthaler, T., Stack, S., Till, B., Sinyor, M., Pirkis, I., Garcia, D., Rockett, I. R. H., \& Tran, U. S. (in press). Suicides in the United States after the release of 13 Reasons Why: Time series analysis. JAMA Psychiatry. Available at: https://iamanetwork.com/journals/iamapsychiatry/ fullarticle $/ 2734859$ ? guestAccessKey $=$ dd50899b-1af3-464a-af48-o5off6b$6139 \mathrm{~d} \& u$ tm_source $=$ For_The_Media\&utm_medium $=$ referral $\& u$ tm_campaign $=f t m \_$links\&utm_content $=t f l \& u t m \_t e r m=052919$

Niederkrotenthaler, T., \& Till, B. (under review). Effects of suicide awareness materials on individuals with recent suicidal ideation or attempt: Randomized controlled online trial. Unpublished Manuscript.

Niederkrotenthaler, T., Till, B., Kapusta, N. D., Voracek, M., Dervic, K., \& Sonneck, G. (2009). Copycat effects after media reports on suicide: A population-based ecologic study. Soc Sci Med, 69, 1085-109o.

Niederkrotenthaler, T., Voracek, M., Herberth, A., Till, B., Strauss, M., Etzersdorfer, E.,...Sonneck, G. (2010a). The role of media reports in completed and prevented suicide - Werther versus Papageno effects. Br I Psychiatry, 197, 234-243.

Niederkrotenthaler, T., Voracek, M., Herberth, A., Till, B., Strauss, M., Etzersdorfer, E.,...Sonneck, G. (2010b). Papageno $v$ Werther effect. BMI, 341, 5841.

Niederkrotenthaler, T., Fu, K., Yip, P. S. F., Fong, D. Y. T., Stack, S., Cheng, Q., \& Pirkis, I. (2012). Changes in suicide rates following media reports on celebrity suicide: A meta-analysis. I Epidemiol Community Health, 66, 233-239.

Phillips, D. P. (1974). The influence of suggestion on suicide: Substantive and theoretical implications of the Werther effect. Am Sociol Rev, 39, 340-354.

Pirkis, J., \& Blood, W. (2001a). Suicide and the media. Part I: Reportage in nonfictional media. Crisis, 22, 146-154.

Pirkis, I. \& Blood, W. (2001b). Suicide and the media. Part II: Portrayal in fictional media. Crisis, 22, 155-162.

Pirkis, I., Blood, W. (2010). Suicide and the news and information media: a critical review. http://www.mindframe-media.info/_data/assets/ pdf file/oo16/5164/Pirkis-and-Blood-2010-Suicide-and-the-news-andinformation-media.pdf

Pirkis, I., Blood, R. W., Beautrais, A., Burgess, P., \& Skehan, I. (2006). Media guidelines on the reporting of suicide. Crisis, 27, 82-87.

Pirkis, I., Dare, A. R., Blood, W., Rankin, B., Williamson, M., Burgess, B., \& Iolley, D. (2009). Changes in media reporting of suicide in Australia between 2000/01 and 2006/07. Crisis, 30, 25-33.
Pouliot, L., Mishara, B. L., \& Iabelle, R. (2011). The Werther effect reconsidered in light of psychological vulnerabilities: Results of a pilot study. I Affect Disord, 134, 488-496.

Ringel E. (1976). The presuicidal syndrome. Suicide Life Threat Behav, 6 , 131-149.

Samaritans. (2017). Media guidelines: Factsheet drama portrayals. Retrieved from: https://www.samaritans.org/sites/default/files/kcfinder/files/press/ Samaritans\%2omedia\%2ofactsheet $\% 20-\% 20$ drama $\% 20$ portrayal.pdf

Schlichthorst, M., King, K. E., Spittal, M. I., Reifels, L., Phelps, A. \& Pirkis, I. (2018). Using a television documentary to prevent suicide in men and boys. Australas Psychiatry, 26, 160-165.

Schmidtke, A., \& Häfner, H. (1988). The Werther effect after television films: New evidence for an old hypothesis. Psychol Med, 18, 665-676.

Shneidman, E. S. (1995). Suicide as psychache: A clinical approach to self-destructive behavior. Lanham, MD: Aronson.

Sisask, M., \& Värnik, A. (2012). Media roles in suicides prevention: A systematic review. Int I Environ Res Public Health, 9, 123-138.

Stack, S. (1992). Social correlates of suicide by age. Media impacts. In A. A Leenaars (Ed.), Life span perspectives of suicide: Time lines in the suicidal process (pp. 187-214). New York: Plenum.

Stack, S. (2005). Suicide in the media: A quantitative review of studies based on nonfictional stories. Suicide Life Threat Behav, 35, 121-133.

Till, B., Arendt, F., Scherr, S., \& Niederkrotenthaler, T. (2019). Effect of educative suicide prevention news articles featuring experts with vs without personal experience of suicidal ideation: A randomized controlled trial of the Papageno effect. I Clin Psychiatry, 80, $17 m 11975$

Till, B., \& Niederkrotenthaler, T. (2014). Vom Werther-zum Papageno-Effekt. Die Rollen von Medien in der Suizidprävention [From Werther to Papageno effect. The role of the media in suicide prevention]. IATROS - Neurologie \& Psychiatrie, 6, 27-30.

Till, B., Strauss, M., Sonneck, G., \& Niederkrotenthaler, T. (2015). Determining the effects of films with suicidal content: a laboratory experiment. Br I Psychiatry, 207, 72-78.

Till, B., Tran, U. S., Voracek, M. \& Niederkrotenthaler, T. (2017). Papageno vs. Werther effect online: Randomized controlled trial of beneficial and harmful impacts of educative suicide prevention websites. Br I Psychiatry, 211, 109-115.

World Health Organization. (2017). Preventing suicide. A resource for media professionals - Update 2017. Genva, Switzerland: World Health Organization.

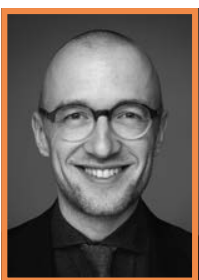

THOMAS NIEDERKROTENTHALER is head of the Unit Suicide Research at the Center for Public Health, Medical University of Vienna, Austria. His team has coined the Papageno effect and has published more than 100 articles in the area of media and suicide. He is co-chair of IASP's Media \& Suicide Special Interest Group.

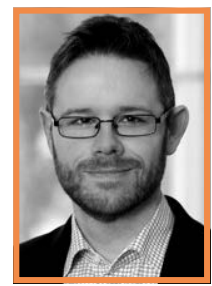

BENEDIKT TILL, DSc, is Associate Professor at the Unit Suicide Research \& Mental Health Promotion, Department of Social and Preventive Medicine, Center for Public Health, Medical University of Vienna, and board member of the Wiener Werkstaette for Suicide Research. Photo: Medical University of Vienna/Matern. 